\title{
Serum prostate-specific antigen in a community-based population of healthy Japanese men: lower values than for similarly aged white men
}

\author{
J.E. OESTERLING*, Y. KUMAMOTO†, T. TSUKAMOTO $\dagger$, C.J. GIRMAN $\ddagger$, H.A. GUESS $\ddagger$, N. MASUMORI $\dagger$. \\ S.J. JACOBSEN§ and M.M. LIEBER \\ *Division of Urology and the Michigan Prostate Center, University of Michigan, Ann Arbor, Michigan, USA, †Department of \\ Urology, Sapporo Medical College, Sapporo, Japan, $¥$ Merck Research Laboratories, Blue Bell, Pennsylvania, USA, §Department of \\ Health Sciences Research, Section of Clinical Epidemiology and, qDepartment of Urology, Mayo Clinic and Foundation, Rochester, \\ Minnesota, USA
}

Objective To determine whether the age-specific reference ranges for serum prostate-specific antigen (PSA) concentration generated for white men are applicable to other races.

Patients and methods Three-hundred and thirty-five healthy Japanese men, aged 40-79 years, residing in the small fishing village of Shimamaki-mura, Japan, agreed to enter this prospective, community-based study. All underwent a detailed clinical evaluation that included a serum PSA determination, a digital rectal examination and a transrectal ultrasound. Twohundred and eighty-six (85\%) completed the prostatic evaluation and had no evidence of prostate cancer by any one of the three diagnostic tests; these men formed the study population on which all analyses were performed.

Results The serum PSA concentration correlated directly with patient age $(r=0.33 ; P<0.001)$ and prostatic volume $(r=0.57 ; P<0.001)$. PSA density (PSAD) also was directly proportional to age $(r=0.30 ; P<0.001)$. Adjusting for age, the serum PSA concentration was lower for Japanese men than for white men
$(P<0.001)$. Thus, the recommended age-specific reference ranges (95th percentile) for serum PSA for Japanese were lower as well: $0.0-2.0 \mathrm{ng} / \mathrm{mL}$ for $40-49$ years; $0.0-3.0 \mathrm{ng} / \mathrm{mL}$ for $50-59$ years; $0.0-4.0 \mathrm{ng} / \mathrm{mL}$ for $60-69$ years; and $0.0-5.0 \mathrm{ng} / \mathrm{mL}$ for 70-79 years. Based on transrectal ultrasoundvolume determinations, the lower serum PSA concentrations in Japanese men are due in large part to their smaller prostate glands as compared with white men $(P<0.001)$.

Conclusions These findings confirm the earlier observations that serum PSA, prostatic volume and PSAD are age-dependent. However, because of physiological differences among the two races, partly due to the size of the prostate gland, the age-specific reference ranges for serum PSA are lower for Japanese men than for white men. Because of these racial differences, it is now crucial to conduct a similar investigation among black men.

Keywords Prostate-specific antigen, age-specific reference ranges, Japanese, white men, race

\section{Introduction}

Prostate-specific antigen (PSA) is the most clinically useful tumour marker available today for the diagnosis and management of prostate cancer [1]. Nevertheless, because it is produced by all types of prostatic tissue normal, benign hyperplastic and cancerous - it lacks sufficient sensitivity and specificity to be the 'perfect' tumour marker for the detection of early prostate cancer.

Accepted for publication 12 October 1994

This study was funded, in part, by research grants from Merck Research Laboratories as part of the BPH Natural History Study Group and the National Institutes of Health (AR30582).
To further improve PSA as a screening test for prostate cancer, numerous investigators have developed and explored various concepts. These include: (i) PSA density (PSAD), which is the quotient of the serum PSA concentration divided by the volume of the prostate gland [2,3]; (ii) PSA velocity (PSAV), which is the longitudinal change in serum PSA level over time [4,5]; (iii) free versus complexed serum PSA, which refers to the ratio

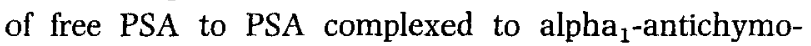
trypsin $(\mathrm{ACT})$ in the serum [6,7]; and (iv) age-specific reference ranges as opposed to the single reference range of $0.0-4.0 \mathrm{ng} / \mathrm{mL}$ for men of all ages $[8,9]$.

In a recent investigation, Oesterling et al. examined the distribution of serum PSA values in a population of 
men with no evidence of prostate cancer but who were at risk of developing the condition [8]. Five-hundred and thirty-seven healthy men were chosen randomly from Olmsted County, Minnesota, USA to participate; all were white and between 40 and 79 years of age, and underwent a detailed clinical evaluation that included a serum PSA determination, a meticulous digital rectal examination (DRE) and a transrectal ultrasound (TRUS). Fourhundred and seventy-one men (88\%) completed the protocol and had no evidence of prostate cancer by any of these diagnostic tests. Based on data from this population, the serum PSA concentration correlates directly with age $(r=0.43 ; P<0.001)$. For a healthy 60-yearold man with no evidence of prostate cancer, the serum PSA concentration increases by approximately $3.2 \%$ per year $(0.04 \mathrm{ng} / \mathrm{mL} / \mathrm{y}$; Tandem-R or IMx PSA assay). Because of this relationship between PSA and age, the upper limit of normal for serum PSA increases with advancing age. Using the 95 th percentile, these investigators determined the upper limit of normal to be $2.5 \mathrm{ng} / \mathrm{mL}$ for men aged $40-49$ years, $3.5 \mathrm{ng} / \mathrm{mL}$ for men aged $50-59$ years, $4.5 \mathrm{ng} / \mathrm{mL}$ for men $60-69$ years and $6.5 \mathrm{ng} / \mathrm{mL}$ for men $70-79$ years.

These results as well as those from other independent investigations $[9,10]$ confirming the correlation between serum PSA and patient age, however, were obtained from white men. No data are available for either black or Asian men. In this report the serum PSA findings from a community-based study involving men from a Japanese fishing village are presented, and age-specific reference ranges for serum PSA in Japanese men are given.

\section{Methods}

\section{Patient population}

Between December 1990 and March 1992, all men aged 40-79 years residing in Shimamaki-mura, a small fishing village in northern Japan, with no history of prostate cancer, prostatectomy or other specified conditions that interfere with voiding function were invited to participate in a prospective study to assess the natural history of benign prostate hyperplasia (BPH). The study design and participant selection process were very similar to those for the community-based population study performed in Olmsted County, Minnesota, USA [11]. Of the 682 men invited, 335 (49\%) agreed to participate. All underwent a detailed clinical evaluation that included a serum PSA determination, a DRE and a TRUS. Forty-five men (13\%) either met exclusion criteria or did not complete all three diagnostic tests, and were excluded from further analysis. Thirty-six (11\%) underwent a TRUS-guided biopsy of the prostate, four of whom (11\%) were found to have cancer. These latter men also were excluded from participation.
Thus, 286 men (85\%) completed the protocol and had no evidence of prostate cancer by any of the three diagnostic tests; these men formed the study population on which all analyses were performed. The mean age \pm standard deviation was $61 \pm 10.3$ years; $47(16 \%)$ were between 40 and $49,64(22 \%)$ between 50 and $59,106(37 \%)$ between 60 and 69, and $69(24 \%)$ between 70 and 79 years of age.

\section{Techniques}

All serum PSA concentrations were determined with the same IMx PSA assay (Abbott Laboratories; Abbott Park, Illinois, USA). The standard reference range for this assay is $0.0-4.0 \mathrm{ng} / \mathrm{mL}$ [12]. All PSA determinations were made prior to any prostatic manipulations, including DRE and TRUS. The DRE was performed with the patient in the knee-chest position.

The TRUS was performed similarly for all men using a $7.5 \mathrm{MHz}$, biplanar endorectal transducer. In addition to assessing the echogenic pattern of the prostate gland, three measurements were made to calculate the prostatic volume. The anterior-posterior (AP) and transverse (TR) diameters were measured at their respective maximal dimensions, whereas the superior-inferior (SI) diameter was measured at the maximal length from the base to the apex of the prostate in the midline sagittal plane. The prostatic volume was calculated from the formula of a prolate ellipsoid, Volume $=0.52(\mathrm{TR} \times \mathrm{AP} \times \mathrm{SI})$ [13] For this investigation, PSAD was calculated by dividing the serum PSA concentration by the prostatic volume, as determined from TRUS.

Any patient with an elevated serum PSA concentration, abnormal DRE result or suspicious lesion on TRUS was evaluated for a prostatic malignancy. If the DRE and TRUS were unremarkable but the serum PSA level was elevated $(>4.0 \mathrm{ng} / \mathrm{mL}$ ), a sextant biopsy (three cores from each side) of the prostate was performed. An abnormal DRE or TRUS result, irrespective of serum PSA level, prompted a biopsy of the area in question; in addition, a sextant biopsy of the remaining prostate was performed.

\section{Statistical analysis}

Descriptive statistics were calculated for the entire study cohort and for 10-year age groups for the clinical parameters, PSA level, prostatic volume and PSAD. Because of the log-normal distribution, PSA levels, prostatic volumes and PSAD values were log-transformed for analysis. Pearson product-moment correlation coefficients were calculated to measure the association between serum PSA and age, prostatic volume and age, PSA and prostatic volume, and PSAD and age. 
Least-squares regression models were constructed using the transformed data to evaluate the association between prostatic volume and age jointly with serum PSA levels. Using the regression models, the 95 th percentile was determined as the upper limit of normal (reference range) for the midpoint of each 10-year age group for the serum PSA concentration and PSAD [14]. For prostatic volume, the 97.5th percentile was used as the upper limit of normal and the 2.5th percentile as the lower limit of normal for the midpoint of each 10-year age group. For all analyses, a $P$-value $<0.05$ was considered statistically significant.

Nomograms portraying the distribution of serum PSA levels, prostatic volumes and PSAD values as a function of age were generated based on the least-squares regression models. A nomogram depicting the distribution of serum PSA levels as a function of prostatic volume also was constructed in a similar manner.

\section{Results}

With regard to the outcome variables, the median (25th, 75th percentiles) serum PSA concentration for the entire study group was $0.8(0.5,1.5) \mathrm{ng} / \mathrm{mL}$, the median prostatic volume was $18(15,21) \mathrm{mL}$ and the median PSAD was $0.05(0.03,0.08) \mathrm{ng} / \mathrm{mL} / \mathrm{mL}$.

\section{Serum PSA and age}

In general, the median serum PSA value increased with each decade of age (Table 1). Between 40 and 49 years of age, no individual had a serum PSA level $>4.0 \mathrm{ng} / \mathrm{mL}$, between 50 and 59 years, one (2\%), between 60 and 69 years, three ( $3 \%$ ), and between 70 and 79 years, five $(7 \%)$ individuals had a serum PSA concentration above the standard reference range $(0.0-4.0 \mathrm{ng} / \mathrm{mL})$ and no clinical evidence of prostate cancer. Overall, nine men (3\%) had a serum PSA level $>4.0 \mathrm{ng} / \mathrm{mL}$.

The serum PSA concentration as a function of age for
Table 1 Serum PSA concentration, prostatic volume and PSA density as a function of age

\begin{tabular}{llll}
\hline $\begin{array}{l}\text { Age range } \\
\text { (years) }\end{array}$ & $\begin{array}{l}\text { Serum PSA } \\
(\mathrm{ng} / \mathrm{mL})\end{array}$ & $\begin{array}{l}\text { Prostatic volume } \\
(\mathrm{mL})\end{array}$ & $\begin{array}{l}\text { PSA density } \\
(\mathrm{ng} / \mathrm{mL} / \mathrm{mL})\end{array}$ \\
\hline $40-49$ & $0.6^{*}$ & 16.8 & 0.04 \\
& $(0.4 ; 0.8) \dagger$ & $(14.5 ; 18.5)$ & $(0.03 ; 0.05)$ \\
$50-59$ & 0.7 & 17.4 & 0.04 \\
& $(0.5 ; 1.2)$ & $(15.4 ; 22.2)$ & $(0.03 ; 0.07)$ \\
$60-69$ & 0.9 & 18.5 & 0.05 \\
& $(0.5 ; 1.5)$ & $(15.7 ; 21.2)$ & $(0.03 ; 0.07)$ \\
$70-79$ & 1.4 & 19.1 & 0.07 \\
& $(0.7 ; 2.1)$ & $(15.8 ; 25.1)$ & $(0.04 ; 0.09)$ \\
& & & \\
\hline
\end{tabular}

* Median value. $\nmid 25$ th and 75 th percentiles, respectively

all 286 men is presented in Fig. 1. Over the entire age range, the serum PSA concentration correlated directly with age $(r=0.33 ; P<0.001)$. Based on the regression analysis of these cross-sectional data, the serum PSA concentration would increase by approximately $2.6 \%$ per year. For a 60-year-old man, this would correspond to an increase of $0.02 \mathrm{ng} / \mathrm{mL}$ over the following year. The nomogram for serum PSA with regard to patient age also is shown in Fig. 1. Based on these data, the appropriate upper limit of normal (95th percentile) for the serum PSA concentration increases with age, from $2.0 \mathrm{ng} / \mathrm{mL}$ for a 45 -year-old man to $5.0 \mathrm{ng} / \mathrm{mL}$ for a 75 -year-old man. The estimated reference range for each 10 -year age group is given in Table 2.

\section{Prostatic volume and age}

Like PSA, the median prostatic volume increased with each decade of life (Table 1). No man between 40 and 59 years of age had a prostate gland that was $>50 \mathrm{~mL}$ in size. Between 60 and 79 years, four men $(2 \%)$ had a prostate $>50 \mathrm{~mL}$ for two of these, the prostate was $>75 \mathrm{~mL}$.
Fig. 1. Serum prostate-specific antigen (PSA) concentration as a function of patient age. Scattergram of the individual serum PSA values for all 286 men, with a nomogram demonstrating the 2.5 th, 5 th, 25th, 50th, 75th, 95th, and 97.5th percentiles for serum PSA according to age.

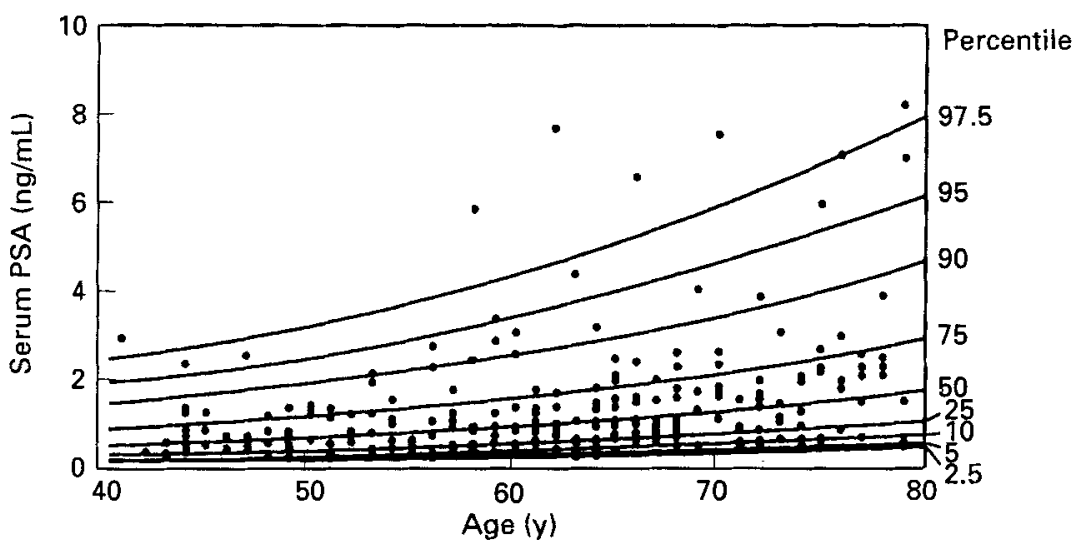


Table 2 Age-specific reference ranges* for serum PSA concentration, prostatic volume and PSA density

\begin{tabular}{llcl}
\hline $\begin{array}{l}\text { Age range } \\
\text { (years) }\end{array}$ & $\begin{array}{l}\text { Serum PSA } \\
(\mathrm{ng} / \mathrm{mL})\end{array}$ & $\begin{array}{l}\text { Prostatic volume } \\
(\mathrm{mL})\end{array}$ & $\begin{array}{l}\text { PSA density } \\
(\mathrm{ng} / \mathrm{mL} / \mathrm{mL})\end{array}$ \\
\hline $40-49$ & $0.0-2.0$ & $9-33$ & $0.0-0.10$ \\
$50-59$ & $0.0-3.0$ & $9-35$ & $0.0-0.12$ \\
$60-69$ & $0.0-4.0$ & $10-37$ & $0.0-0.15$ \\
$70-79$ & $0.0-5.0$ & $11-40$ & $0.0-0.18$ \\
\hline
\end{tabular}

* For serum PSA concentration and PSA density the upper limit of normal was defined as the 95th percentile for the midpoint of age range from regression analysis: for prostatic volume the 97.5 th percentile was used to define the upper limit. The lower limit was set at 0.0 for PSA concentration and PSA density and 2.5th percentile for prostatic volume

The prostatic volume for each study participant is plotted by age in Fig. 2. For the entire age group the prostatic volume correlated directly with age $(r=0.19$; $P<0.01)$. The regression analysis suggests that the prostatic volume would increase by approximately $0.6 \%$ /year. For a 60 -year-old man this would correspond to an increase of $0.11 \mathrm{~mL}$ over the ensuing year. The nomogram for prostatic volume as a function of age also is presented in Fig. 2, and the calculated reference range (2.5th percentile to 97.5 th percentile) for prostatic volume for each 10-year age group is presented in Table 2 .

\section{Serum PSA and prostatic volume}

The individual serum PSA value as a function of the prostatic volume is plotted in Fig. 3. Over the entire range of prostatic sizes, the serum PSA concentration correlated directly with prostatic volume ( $r=0.57$; $P<0.001$ ). Based on the regression analysis of these cross-sectional data, the serum PSA concentration would increase by $5.4 \%$ per millilitre of prostatic tissue. For a $25 \mathrm{~mL}$ prostate gland, this would mean an increase of
$0.07 \mathrm{ng} / \mathrm{mL}$ for each millilitre of enlargement in size. The nomogram for serum PSA concentration with regard to prostatic volume also is given in Fig. 3. The results of the regression analysis suggest that $33 \%$ of the variance in PSA can be accounted for by prostatic volume, and age accounts for an additional 5\% $(P<0.001)$.

\section{PSAD and age}

While PSA and prostatic volume both increased with age, the median PSAD level increased only moderately with each decade of life (Table 1). For the study participants between the ages of 40 and 49 years, one man (2\%) had a PSAD $>0.15 \mathrm{ng} / \mathrm{mL} / \mathrm{mL}$ (the previously suggested upper limit for PSAD to distinguish early prostate cancer from $\mathrm{BPH}(15)$; between 50 and 59 years, 1 (2\%); between 60 and 69 years, $5(5 \%)$; and between 70 and 79 years, $6(9 \%)$ had a PSAD above this cutpoint. For the entire study population, 13 men (5\%) had a PSAD value $>0.15 \mathrm{ng} / \mathrm{mL} / \mathrm{mL}$.

Each study participant's individual PSAD value as a function of age is presented in Fig. 4. For the entire age group, PSAD is correlated directly with age, as is suggested by the $r$-value of $0.29(P<0.001)$. Based on the regression analysis, the PSAD would increase by $1.9 \% /$ year. For a 60 -year-old man, this would correspond to an increase of $0.001 \mathrm{ng} / \mathrm{mL} / \mathrm{mL}$ over one year's time. The nomogram for PSAD with regard to patient age is provided in Fig. 4, and the appropriate upper limit of normal (95th percentile) for PSAD for each 10-year age group is given in Table 2.

\section{Discussion}

This investigation, based on a community population of healthy Japanese men with no clinical evidence of prostate cancer, is the first study to define 'normal levels' for serum PSA level as well as for prostatic volume and PSAD among non-whites. All previous studies examining these variables involved white populations [8-10].

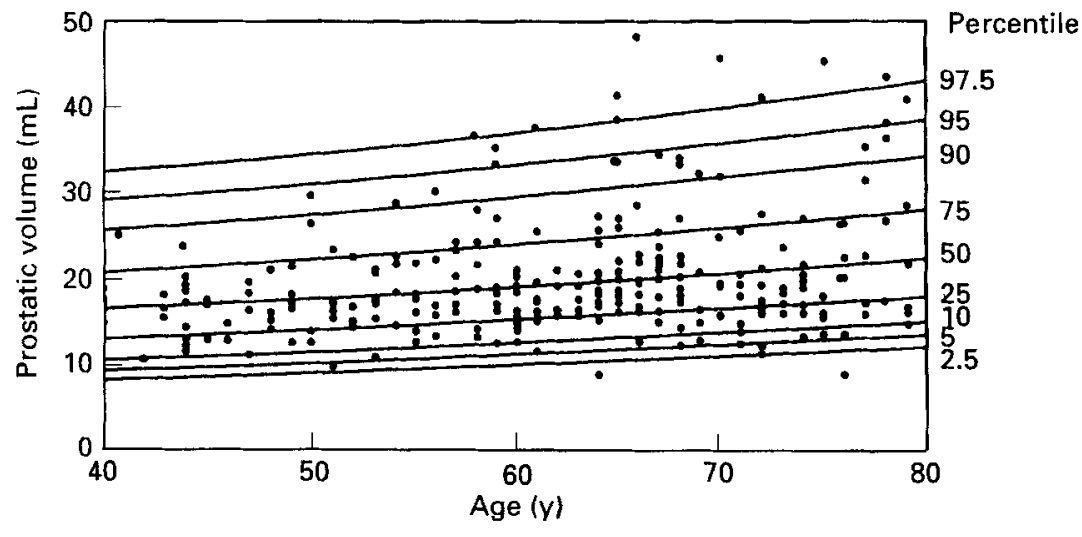

Fig. 2. Prostatic volume as a function of patient age. Scattergram of the individual prostatic volumes for all 286 men, with a nomogram demonstrating the 2.5 th, 5 th, 25th. 50th, 75th, 95th, and 97.5th percentiles for prostatic volume according to age. 
Fig. 3. Serum prostate-specific antigen (PSA) concentration as a function of prostatic volume. Scattergram of the individual values for all 286 men, with a nomogram demonstrating the 2.5 th, 5 th, 25th, 50th, 75th, 95th, and 97.5th percentiles for serum PSA according to prostatic volume.
Fig. 4. Prostate-specific antigen density (PSAD) as a function of patient age. Scattergram of the individual PSAD values for all 286 men, with a nomogram demonstrating the 2.5 th, 5 th, $25 \mathrm{th}$, 50th, 75th. 95th, and 97.5 th percentiles for PSAD according to age.
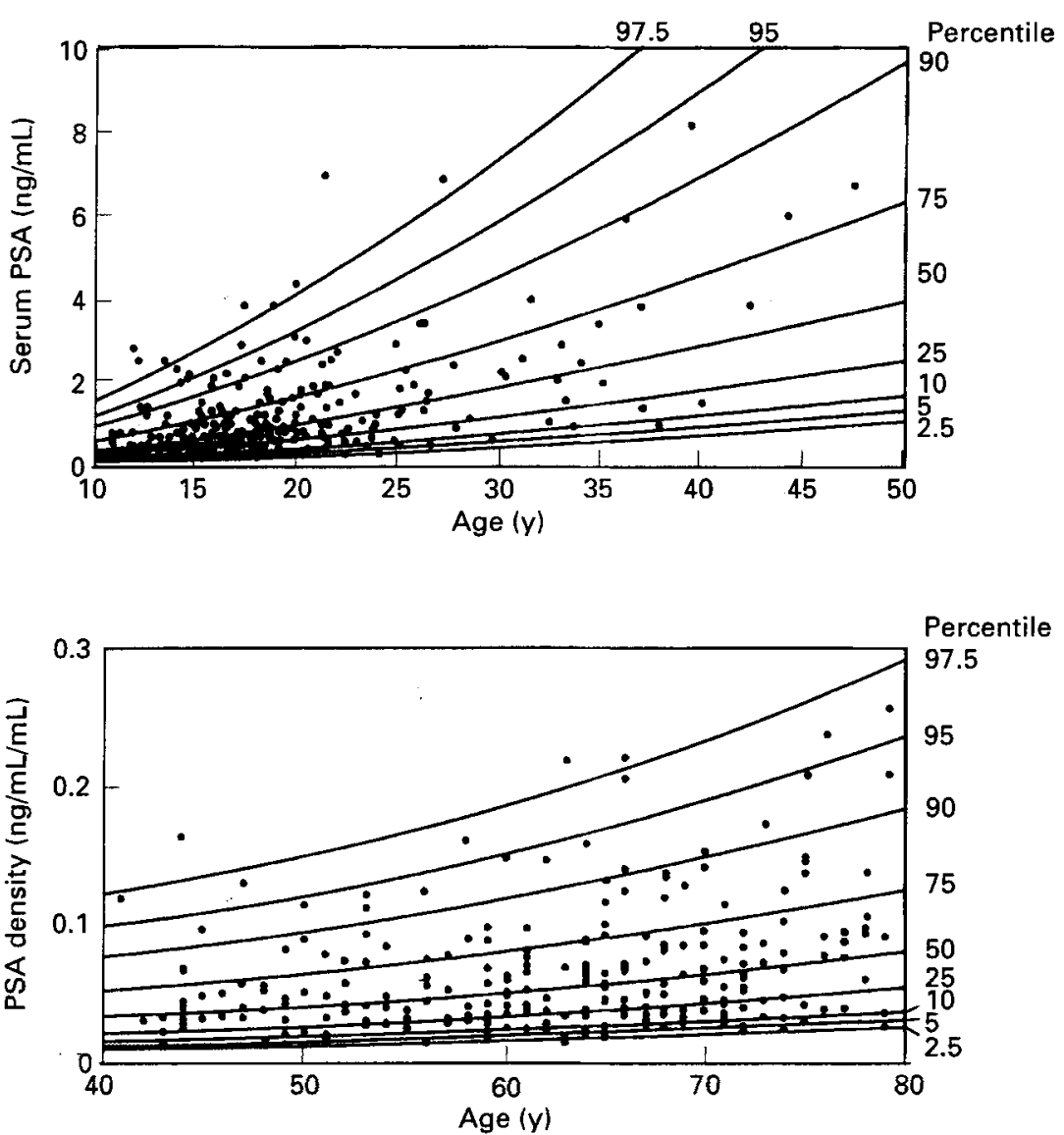

Thus, this investigation affords a valuable opportunity not only to describe the appropriate reference ranges for Japanese men but also to determine if there are racial differences.

In the current study, the serum PSA concentration was found to correlate directly with patient age $(r=$ $0.33)$ and with prostatic volume $(r=0.57)$. PSAD and, to a lesser degree, prostatic volume also correlated directly with patient age $(r=0.29$ and 0.19 , respectively). These findings are in agreement with the results of previous investigations. Oesterling et al., examining 471 healthy men from OImsted County, Minnesota, USA, found the correlation coefficient between serum PSA and age, prostatic volume and age, and PSAD and age to be 0.43. 0.43, and 0.25, respectively [8]. Collins et al. examined these relationships in 472 men with benign prostates from central Scotland [10]. The correlation coefficient for serum PSA and patient age in this community-based population was 0.37 , and for prostatic volume and age, it was 0.44 . Most recently, Dalkin et al. examined the relationship between serum PSA and age in 728 men older than 50 years of age who had no clinical evidence of prostate cancer [9]. They also found the serum PSA level to increase with advancing age at a statistically significant rate $(P<0.001)$. Taken together, these large-scale studies clearly indicate that both the serum PSA concentration and prostatic volume are dependent upon the patient's age.

Because of these age-dependent relationships, Oesterling et al. as well as Dalkin et al. developed, for white men, age-specific reference ranges for serum PSA (Table 3). These reference ranges are somewhat higher than those derived for the Japanese men (Table 2). Across all age ranges, from 40 to 79 years of age, the upper limit of normal for serum PSA for Japanese men is lower

Table 3 Age-specific reference ranges* for serum as determined from two investigations involving white men

\begin{tabular}{lll}
\hline Age range (years) & \multicolumn{2}{l}{ Age-specific reference ranges $(\mathrm{ng} / \mathrm{mL})$} \\
\cline { 2 - 3 } & Oesterling et al. [8] & Dalkin et al. [9] \\
\hline $40-49$ & $0.0-2.5$ & - \\
$50-59$ & $0.0-3.5$ & $0.0-3.5$ \\
$60-69$ & $0.0-4.5$ & $0.0-5.4$ \\
$70-79$ & $0.0-6.5$ & $0.0-6.3$ \\
\end{tabular}

* The upper limit of normal was defined as the 95th percentile for the midpoint of each age range using regression analysis. The lower limit was set at 0.0 
than for white men. This implies that a given serum PSA value for a Japanese man has a different clinical meaning than the same value for a same-aged white man. Thus, a serum PSA concentration of $4.2 \mathrm{ng} / \mathrm{mL}$ would be considered elevated for a 62 -year-old Japanese, whereas it would be normal for the same-aged white man. Nevertheless, as occurs for the white race, agespecific reference ranges make serum PSA a more sensitive tumour marker for younger Japanese men $(<70$ years of age) and a more specific tumour maker for older Japanese ( $>70$ years of age). This is exactly what is desired for any tumour marker. Although the Japanese PSA values were determined by the IMx PSA assay, the derived age-specific references ranges are applicable to the Tandem-R PSA assay (Hybritech, Inc., San Diego, California, USA) [16].

Establishing PSA reference ranges that are racespecific as well as age-specific is intended to produce reference ranges with similar levels of specificity in different racial groups. However, the positive predictive value of these PSA reference ranges will still be higher in white men than in Japanese men, because the prevalence of clinically significant prostate cancer is much higher amongst the former. Thus, a serum PSA value that is elevated above the appropriate race-specific, agespecific serum PSA reference range is more likely to represent prostate cancer in a white man than in a Japanese man. Further experience with clinical use of these age reference ranges is needed to quantify the extent of these differences.

The most likely explanation for this difference in the age-specific reference ranges for PSA relates to the size of the prostate gland for the two races. Across all age ranges, the prostates of white men are larger than those of Japanese (Table 4) [10]. Berry et al., when examining the results of several autopsy series from western societies, also noted that white men have large prostates [17]. The findings of that retrospective, autopsy review are in

Table 4 Age-specific reference ranges* for prostatic volume and PSA density [8] in white men

\begin{tabular}{lll}
\hline $\begin{array}{l}\text { Age range } \\
\text { (years) }\end{array}$ & $\begin{array}{l}\text { Prostatic volume } \\
(\mathrm{mL})\end{array}$ & $\begin{array}{l}\text { PSA density } \\
(\mathrm{ng} / \mathrm{mL} / \mathrm{mL})\end{array}$ \\
\hline $40-49$ & $13-51$ & $0.0-0.08$ \\
$50-59$ & $15-60$ & $0.0-0.10$ \\
$60-69$ & $17-70$ & $0.0-0.11$ \\
$70-79$ & $20-82$ & $0.0-0.13$
\end{tabular}

* For PSA density, the upper limit of normal was defined as the 95th percentile for the midpoint of age range from regression analysis; for prostatic volume, the 97.5 th percentile was used to define the upper limit. The lower limit was set at 0.0 for PSA density and 2.5 th percentile for prostatic volume total agreement with the results that Oesterling et al. obtained from TRUS measurements of the Olmsted County men. Without question, the bigger the prostate, the more epithelial cells that produce and secrete PSA. Larger prostates, in general, also tend to have a greater degree of obstruction of the prostatic ducts and acini due to BPH tissue. In addition, larger prostates often contain some inflammation not routinely present in smaller, less congested prostates. Even mild, subclinical degrees of inflammation can cause a breakdown of the normal physiological barriers (basal cells lining the acini, basement membrane of the acini, the prostatic stroma, capillary endothelial basement membrane and the capillary endothelial cells) that routinely keep PSA in the prostatic ductal system [18]. Because of these phenomena, more PSA will diffuse into the stroma of the larger prostate, where it can enter the general circulation via the lymphatics and capillaries. However, prostatic size alone does not account for all of the difference in serum PSA levels between Japanese and white men. The difference in serum PSA concentrations between these two races remains statistically significant $(P<0.001)$, even after adjusting for both prostatic size and patient age.

The elevations of serum PSA levels beyond that which can be accounted for by prostatic size alone may reflect differences between Japanese and white men and the problems of clinically, non-detectable prostate cancer. While the autopsy prevalence of previously unsuspected ('latent') prostate cancer shows little racial or geographic variation, the autopsy prevalence of 'proliferative' (more extensive and less well differentiated) latent prostate cancer does show racial and geographic variation similar to that seen with clinically diagnosed prostate cancer $[19,20]$.

With regard to $\mathrm{PSAD}$, the values obtained for the Japanese cohort are greater than those observed for the white cohort (Table 4). This is due to the fact that the prostate glands of Japanese men are significantly smaller for the corresponding serum PSA values as compared with white men. As a result, the age-specific reference ranges for PSAD are higher for Japanese men, while the age-specific reference ranges for serum PSA are lower. When compared with the standard reference range for PSAD $(0.0-0.15 \mathrm{ng} / \mathrm{mL})$ [15], these age-specific reference ranges for Japanese make PSAD a more sensitive parameter in men $<60$ years of age and a more specific parameter in men $>60$ years of age.

In summary, this investigation of Japanese men confirms the earlier observation that serum PSA, prostatic volume and PSAD are age-dependent. Because of this phenomenon, it is appropriate to have age-specific reference ranges for these parameters in Asian men, as has been recommended recently for white men. However, 
because of physiological differences between the two races, particularly with regard to the size of the prostate gland, the age-specific reference ranges for serum PSA are lower and the age-specific reference ranges or PSAD are higher for Japanese than for white men. Thus, with regard to serum PSA, prostatic volume and PSAD values, there are racial differences - a most important finding. It is now crucial to conduct a similar investigation in black men, especially since prostate cancer is more prevalent, develops at an earlier age, and has a higher death rate in this race [21]. By knowing the proper reference ranges for these parameters in black men, a more accurate and meaningful interpretation of values obtained for serum PSA, prostatic volume and PSAD can be made on an individual basis. Hopefully, this will advance our cause toward earlier detection of prostate cancer among black men.

\section{References}

1 Oesterling JE. Prostate specific antigen: a critical assessment of the most useful tumor marker for adenocarcinoma of the prostate. J Urol 1991; 145: 907-23

2 Benson MC. Whang IS, Pantuck $A$ et al. Prostate specific antigen density: a means of distinguishing benign prostatic hypertrophy and prostate cancer. I Urol 1992; 147: 815-6

3 Benson MC, Whang IS, Olsson CA, McMahon DJ, Cooner WH. The use of prostate specific antigen density to enhance the predictive value of intermediate levels of serum prostate specific antigen. I Urol 1992; 147: 817-21

4 Carter HB, Pearson JD, Metter EJ et al. Longitudinal evaluation of prostate-specific antigen levels in men with and without prostate disease. JAMA 1992; 267: 2215-20

5 Oesterling JE, Chute CG, Jacobsen SJ et al. Longitudinal changes in serum PSA (PSA velocity) in a communitybased cohort of men. J Urol 1993; 149: 412A

6 Lilja H, Christensson A, Dahlén U et al. Prostate-specific antigen in human serum occurs predominantly in complex with alpha-1-antichymotrypsin. Clin Chem 1991; 37: 1618-25

7 Stenman UH, Leinonen J, Alfthan H, Rannikko S, Tuhkanen $\mathrm{K}$. Alfthan 0 . A complex between prostatespecific antigen and alpha-1-antichymotrypsin is the major form of prostate-specific antigen in serum of patients with prostatic cancer. Cancer Res 1991; 51: 222-6

8 Oesterling JE, Jacobsen SJ, Chute CG et al. Serum prostatespecific antigen in a community-based population of healthy men: establishment of age-specific reference ranges. JAMA 1993; 270: 860-4

9 Dalkin BL, Ahmann FR, Kopp JB. Prostate specific antigen levels in men older than 50 years without clinical evidence of prostatic carcinoma. J Urol 1993; 150: 1837-9

10 Collins GN, Lee RJ. McKelvie GB, Rogers ACN, Hehir M. Relationship between prostate specific antigen, prostate volume, and age in the benign prostate. Br I Urol 1993; 71: 445-50

11 Chute CG, Panser LA, Girman CJ et al. The prevalence of prostatism: a population-based survey of urinary symptoms. J Urol 1993; 150: 85-9

12 Klee GG, Dodge LA, Zincke H, Oesterling JE. Measurement of serum prostate specific antigen using IMx prostate specific antigen assay. J Urol 1994: 151: 94-8

13 Terris MK, Stamey TA. Determination of prostate volume by transrectal ultrasound. I Urol 1991; 145: 984-7

14 Elveback LR, Guillier CL, Keating FR Jr. Health, normality, and the ghost of Gauss. JAMA 1970; 211: 69-78

15 Cooner WH. Early diagnosis of prostate cancer. In Walsh PC, Retik AB, Stamey TA, Vaughan Jr ED Eds, Campbell's Urology, 6th edn, Update 4. Philadelphia: WB Saunders, 1993: $1-10$

16 Jacobsen SJ, Klee GG, Lílja H, Wright GL Jr, Oesterling JE. Stability of serum prostate specific antigen across laboratory, assay, and storage time. J Urol 1994: in press

17 Berry SJ, Coffey DS, Walsh PC, Ewing LL. The development of human benign prostatic hyperplasia with age. I Urol 1984; 132: 474-9

18 Oesterling JE, Bilhartz DL, Tindall DJ. Clinically useful serum markers for adenocarcinoma of the prostate, II: prostate-specific antigen. Am Urol Assoc Update Ser 1991; 10: $137-44$

19 Breslow NC, Chan CW, Dhom G et al. Latent carcinoma of prostate at autopsy in seven areas. Collaborative study organized by the International Agency for Research on Cancer, Lyons, France. Int J Cancer 1977; 20: 680-8

20 Akazaki K. Stemmermann GN. Comparative study of latent carcinoma of the prostate among Japanese in Japan and Hawail. J Natl Cancer Inst 1973; 50: 1137-44

21 Mebane C, Gibbs T, Horm J. Current status of prostate cancer in North American black males. I Natl Med Assoc 1990; 82: 782-8

\section{Authors}

J.E. Oesterling, MD, Professor, Urologist-in-Chief and Director.

Y. Kumamoto, MD, Professor and Chairman.

T. Tsukamoto, MD, Associate Professor.

C.Y. Girman, Dr PH, Doctor of Public Health.

H.A. Guess, MD, PhD, Distinguished Senior Epidemiologist.

N. Masumori, MD.

S.J. Jacobsen, $\mathrm{MD}, \mathrm{PhD}$, Associate Professor of Epidemiology. M.M. Lieber, MD, Professor.

Correspondence: Dr J.E. Oesterling, Division of Urology, University of Michigan, 1500 East Medical Centre Drive, Ann Arbor, MI 48109, USA. 